\title{
Analisa Praktik Jual Beli Paket Data Intemet Ditinjau Dari Perspektif Hukum Islam
}

\author{
Novanda Eka Nurazizah \\ Institut Agama Islam Negri Ponorogo \\ novandaeka6@gmail.com
}

\begin{abstract}
This study discusses how to practice the sale and purchase of an active period of internet data package in the Pasar Tamansari counter complex concerning the validity period of internet data packet prime card. The incompatibility of the active period of data packet raises a problem that resulted in a loss on one side party. The active period of internet data packets does not match what is in the product packaging. This research used a qualitative research design, conducted in actual life or reality. In this case, the object of research was the Pasar Tamansari counter complex. It is concluded that the law of sale and purchase is valid based on harmonious and conditions of sale and purchase. However, the transaction object is inconsistent with the initial agreement presented by the seller. Here, from the benefits aspects, it is fully unfulfilled because of the defects of the object being traded, then the sale is broken (fasid) or canceled.
\end{abstract}

Keywords: Islamic Law, The Sale and Purchase, Internet Data Packet

\begin{abstract}
Abstrak
Penelitian ini membahas mengenai bagaimana praktik jual beli masa aktif paket data internet di Konter Komplek Pasar Tamansari mengenai masa berlakunya kartu perdana paket data internet. Adanya ketidaksesuaian masa aktif paket data menimbulkan permasalahan yang mengakibatkan kerugian pada salah satu pihak. Masa aktif paket data internet tidak sesuai dengan apa yang ada dalam kemasan produk Penelitian ini adalah penelitian lapangan, yang dilakukan dalam kehidupan atau kenyataan yang sebenarnya. Dalam hal ini objek penelitian adalah Konter Komplek Pasar Tamansari. Disimpulkan bahwa hukum jual beli tersebut sah, karena sesuai dengan rukun dan syarat-syarat jual beli. Akan tetapi pada obyek transaksi terdapat ketidaksesuaian dengan kesepakatan awal yang dipaparkan oleh penjual. Dalam hal ini, maka secara manfaat tidak terpenuhi sepenuhnya karena adanya kecacatan terhadap obyek yang diperjual-belikan, maka jual beli tersebut rusak (fasid) atau batal.
\end{abstract}

Kata Kunci: Hukum Islam, Jual Beli Paket Data Internet 


\section{PENDAHULUAN}

Muamalah dalam arti luas adalah aturan-aturan (hukum-hukum) Allah untuk mengatur manusia kaitanya dengan urusan duniawi dalam pergaulan sosial. Manusia sebagai makhluk sosial memerlukan orang lain agar saling bekerjasama dalam memenuhi kebutuhannya masing masing. (Abdur-Rahman Ghazaly, 2012: 3). Jual beli merupakan akad yang umum digunakan oleh masyarakat, karena untuk memenuhi kebutuhan hidup, masyarakat tidak bisa meninggalkan akad tersebut. Misalnya untuk mendapatkan makanan dan minuman terkadang mereka tidak mampu memenuhi kebutuhan tersebut dengan sendirinya, tetapi sangat membutuhkan dan berhubungan dengan orang lain sehingga memungkinkan terbentuknya akad jual beli. Jual beli merupakan kajian yang harus berkembang sesuai dengan perkembanmgan zaman saat ini mulai dari bentuk model-model dalam system jual beli pun harus bervariatif.

Jual beli merupakan suatu perjanjian tukar-menukar benda (barang) yang mempunyai nilai atas dasar kesepakatan antara kedua belah pihak yang sesuai dengan ketentuan yang dibenarkan oleh syara', maksudnya harus memenuhi rukun-rukun dan syarat-syarat dan hal-hal lain yang ada kaitanya dengan jual beli, berarti tidak sesuai dengan kehendak syara'. (Qomarul Huda, 2011: 52). Tata aturan semacam ini telah lebih dahulu dijelaskan di dalam Al- Qur'an surat An-Nisa ayat 29:

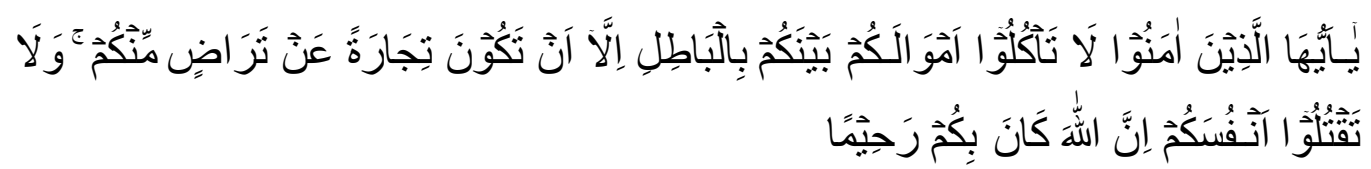

Artinya: "Hai orang-orang yang beriman, janganlah kamu saling memakan harta sesamamu dengan jalan yang batil, kecuali dengan jalan perniagaan yang Berlaku dengan suka sama-suka di antara kamu. dan janganlah kamu membunuh dirimu. Sesungguhnya Allah adalah Maha Penyayang kepadamu." (QS. An-Nisa' ayat: 29)

Ayat ini mengajarkan kepada kita bahwa untuk memperoleh rizki tidak boleh dengan cara yang bathil, yaitu cara yang bertentangan dengan hukum 
Islam misalnya gharar, penipuan, riba, pemaksaan dan lain-lain, selain itu perlu juga didasari dengan rasa saling rela antara masing-masing pihak yang melakukan transaksi. Dasar hukum yang memperbolehkan jual beli ini terdapat dalam Al- Qur'an surat Al-Baqarah ayat 275.

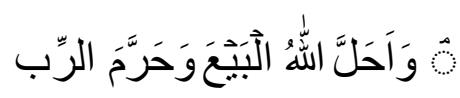

Artinya:"Padahal Allah telah menghalalkan jual beli dan mengharamkan riba" (QS. Al-Baqarah ayat: 275).

Berdasarkan dasar hukum diatas, jelaslah bahwa jual beli memang telah diperbolehkan. Adapun sahnya jual beli tersebut apabila terpenuhinya rukun dan syarat, diantaranya adalah wujud dari obyek transaksi dapat diketahui dengan jelas, dapat diserahkan dan dapat dihargakan. Begitupula dalam akad jual beli yang harus dilakukan berdasarkan keinginannya sendiri tanpa adanya unsur keterpaksaan dari siapapun. Jual beli merupakan bagian dari ta'awun (tolongmenolong). Bagi pembeli menolong penjual yang membutuhkan uang dan begitupun sebaliknaya penjual menolong pembeli yang membutuhkan barang. Maka dari itu jual beli merupakan perbuatan yang mulia dan pelakunya akan mendapat ridho Allah Swt.

Bisnis jual beli paket data internet merupakan bisnis yang memperjualbelikan paket kuota internet. Kuota dalam bajet ini merupakan batasan paket yang diberikan operator yang mana pelanggan dapat menggunakanya untuk akses internet, umunya sekarang dalam hitungan Gigabyte atau disingkat GB atau sama dengan 100 Megabyte (MB). kuota pada paket ini dibagi menjadi beberapa jenis, seperti kuota utama, kuota reguler, kuota 24 jam, kuota bonus,kuota malam, kuota download dan lain sebagainya. Makna dan arti dari kuota-kuota mengacu pada batasan pengggunanya.

Bisnis jual beli paket data internet merupakan sebuah peluang usaha yang menguntungkan, berkembang sangat pesat di era saat ini. Salah satu yang menjalankan bisnis ini adalah konter komplek Pasar Tamansari Sambit Ponorogo, konter ini adalah salah satu tempat yang sangat diminati oleh banyak 
orang karena harganya lebih murah daripada tempat yang lainya, selain menjual paket data, konter tersebut juga menjual pulsa, akssoris hp, kartu prabayar dan lain sebagainya. Berbagai macam paket data juga dijual disini.

Masa katif merupakan waktu dimana kartu prabayar dapat digunakan, jika masa aktif kartu tersebut 1 bulan maka kartu trsebut dapat digunakan selama 1 bulan jika tidak di isi pulsa. Akan tetapi jika dalam waktu kurang dari 1 bulan dari masa aktif kartu prabayar diisi pulsa maka masa aktif kartu tersebut akan diperpanjang. Tetapi sebaliknya, jika kartu tidak diisi pulsa maka masa aktif tersebut akan bertahan sesuai dengan yang tertera dalam produk. Dalam praktiknya di konter komplek Pasar Tamansari menjual paket data dengan masa aktif 2 bulan sesuai yang tertera dalam kemasan, akan tetapi pada kenyataanya setelah pembeli mengaktifkan dan mengecek masa aktif kartu perdana tersebut tidak sesuai dengan apa yang dikatakan oleh penjual dan yang tertera di bungkus produk. hal ini tentu dapat menimbulkan kerugian terhadap konsumen yang membeli di tempat tersebut karena masa aktif dapat mempengaruhi harga. Melalui kejadian ini para pelanggan yang pernah membeli paket data di konter Komplek Pasar Tamansari banyak yang mengeluh dan berpikir ulang lagi kalau membeli paket data di konter tersebut karena merasa dirugikan dengan adanya ketidaksesuaian dari apa yang dikatakan dan bukti nyatanya setelah pelanggan mengaktifkan kartu dan mengecek masa aktifnya.

\section{KERANGKA TEORI}

Pengertian jual beli secara syara'; adalah tukar menukar harta dengan harta untuk memiliki dan memeberikan kepemilikan. Sebagian ulama' memberikan pengertian tukar menukar harta meskipun masih ada dalam tanggungan atau kemanfaatan yang mubah dengan sesuatu yang semisal dengan keduanya, untuk memberikan secara tetap kedua pengertian tersebut mempunyai kesamaan dan mengandung hal-hal antara lain: (1).Jual-beli dilakukan oleh 2 orang yang saling tukar-menukar. (2) Tukar-menukar tersebut atas sesuatu yang dihukumi seperti barang dan dapat mendatangkan manfaat dari transaksi tersebut. (3) Sesuatu 
yang tidak berupa barang/harta atau yang dihukumi sepertinya tidak sah untuk diperjualbelikan. (4) Tukar menukar tersebut hukumnya tetap berlaku, yakni kedua belah pihak memiliki sesuatu yang diserahkan kepadanya dengan adanya ketetapan jual-beli dengan pemilikan yang abadi. (Wahbah Az-Zuhaily, 2005: juz 4). Macam-macam jual beli diantaranya: (1) Menjual barang yang bisa dilihat : Hukunya boleh atau sah jika barang yang dijual memenuhi rukun dan syarat jual beli. (2) Menjual barang yang disifati (memesan barang) ; hukumnya boleh atau sah jika barang yang dijual sesuai dengan sifatnya. (3) Menjual barang yang tidak kelihatan, hukumnya tidak boleh atau sah menjual sesuatu yang suci dan bermanfaat dan tidak diperbolehkan atau tidak sah menjual sesuatu yang najis dan tidak bermanfaat.(Imam Ahmad Bin Husain Mujib: 30). Macam-macam jual beli yang dilarang yaitu: (1) Jual beli gharar, yaitu jual beli yang mengandung unsur penipuan dan penghianatan. (2)Jual beli mulaqih, yaitu jual beli dimana barang yang dijual berupa hewan yang masih dalam bibit jantan sebelum bersetubuh dengan betina.(3) Jual beli mudhamin, yaitu jual beli hewan yang masih dalam perut induknya.(4) Jual beli muhaqolah, yaitu jual beli buahbuahan yang masih ada di tangkainya dan belum layak untuk dimakan.(4). Jual beli munabadzah, yaitu tukar menukar kurma basah dengan kurma kering dan tukar menukar anggur basah dengan anggur kering dengan menggunakan alat ukur takaran. (6). Jual beli mukhabarah, yaitu muamalah dengan penggunaan tanah dengan imbalan bagian dari apa yang dihasilkan oleh tanah tersebut. (7) Jual beli tsunaya, yaitu jual beli dengan harga tertentu, sedangkan barang yang menjadi objek jual beli adalah sejumlah barang dengan pengecualian yang tidak jelas. (8). Jual beli asb al-fahl, yaitu memperjualbelikan bibit pejantan hewan untuk dibiarkkan dalam rahim hewan betina untuk mendapatkan anak.( Amir Syarifuddin, 2003: 207).

\section{METODE PENELITIAN}

Metode adalah cara yang tepat untuk melakukan sesuatu dengan menggunakan pemikiran secara seksama untuk mencapai suatu tujuan. Sedangkan penelitian adalah pemikiran sistematis mengenai berbagai jenis 
masalah yang pemahamanya memerlukan pengumpulan fakta-fakta.( Cholid Narbuko dan Abu Ahmadi, 1997: 1).Penelitian ini adalah penelitian lapangan yaitu, yang dilakukan dalam kehidupan atau kenyataan yang sebenarnya. Dalam hal ini bersumber dari pemilik Konter Komplek Pasar Tamansari. Penelitian ini menggunakan deskriptif analitis yaitu, mengambil masalah atau memusatkan perhatian kepada masalah-masalah yang terjadi sebenarnya saat melakukan penelitian, kemudian hasil penelitianya diolah dan dianalisis untuk diambil kesimpulanya. Dalam hal ini peneliti menemukan masalah pada penjuaalan masa aktif paket data internet di Konter Komplek Pasar Tamansari bahwa masa aktif yang dijual kepada pembeli tidak sama dengan apa yang dikatakan oleh penjual, hal tersebut baru diketahui setelah pembeli mengaktifkan dan mengecek kartu perdana tersebut. kemudian peneliti dapat menyimpulkan apa hukum jual beli yang terjadi dalam masalah. Sumber data ini diperoleh dari (1) Data primer, yaitu data yang diperoleh melalui wawancara dengan pihak-pihak yang terlibat dalam kasus tersebut, sehingga dapat dikontribusikan makna dalam hal ini, peneliti melakukan wawancara kepada pemilik konter dan pembeli kartu paket data intrnet di konter komplek Pasar Tamansari pada tanggal 12 juli 2018. Dalam penelitian ini ada 2 orang yang diwawancari dan ada 3 orang yang dijadikan responden karena mereka merupakan orang yang pernah membeli paket data di konter tersebut dan termasuk orang yang pernah mengalami kasus ketidaksesuaian tentang masa berlaku paket data internet di konter tersebut. (2) Data Sekunder, Data ini diperoleh dari studi kepustakaan antara lain mencakup jurnal, buku-buku, hasil penelitian yang berwujud laporan dan sebagainya serta bahan lain yang terkait dengan penelitian yang dilakukan.

Setelah data diperoleh, maka teknik analisis data yang digunakan yaitu : metode deskriptif analisis dengan pola pikir deduktif yaitu, menjelaskan atau menggambarkan data hasil penelitian di konter komplek Pasar Tamansari tentang Ketidaksesuaian antara yang dikatakan oleh penjual kepada pembeli dengan kenyataan yang sudah dirasakan oleh pembeli. Diawali dengan teoriteori atau dalil yang bersifat umum, seperti teori yang sudah disebutkan diatas dapat diketahui bagaimana akad jual beli tersebut apakah diperbolehkan atau 
termasuk jual beli yang rusak (fasid). Kemudian peneliti mengemukakan kenyataan yang bersifat khusus dari hasil penelitian jual beli masa aktif paket data internet di konter komplek Pasar Tamansari bahwa adanya ketidaksesuaian masa aktif kartu perdana dengan apa yang sudah disepakati di awal, sehingga dalam ini terdapat pihak yang merasa dirugikan, yaitu pembeli karena semakin banyak $\mathrm{Gb}$ yang dibeli maka harganya juga semakin mahal dan disini kenyataanya terdapat konflik masa berlaku atau masa aktif dari kartu perdana tersebut habis sebelum waktu yang tertera dalam kemasan.

\section{PEMBAHASAN}

\section{Gambaran Umum Tentang Counter Komplek Pasar Tamansari}

Konter adalah tempat untuk seseorang memperjual-belikan pulsa. Dari hasil wawancara kepada mas Agus memperoleh hasil data, terdapat dua orang dikonter tersebut, yaitu pemilik toko dan karyawan toko. Konter ini berdiri sejak tahun 2014, sebelum konter ini didirikan pemilik konter bekerja sebagai sales kartu perdana yaitu di Tri selama 2 tahun di XL selama 2 tahun dan di simpati selama 2 tahun. Jadi totalnya 6 tahun pengalaman pemilik konter bekerja di bidang kartu perdana. Konter ini sudah berdiri selama 7 tahun sampek sekarang, dalam konter tersebut ada Agus si pemilik toko dan satu karyawan. Di konter tidak hanya menjual paket data internet saja, akan tetapi menjual produk-produk lainya seperti pulsa handphone, aksesoris handphone, token listrik, jam tangan, flashdisk dan produk-produk lainya. (Agus, 2018). Konter tersebut merupakan tempat yang digemari oleh masyarakat, khususnya oleh pelajar, karena mempunyai harga yang cukup terjangkau, bisa dikatakan lebih murah daripada tempat yang lainya, tempatnya yang sangat strategis dan tidak terlalu jauh dari sekolahan membuat tempat ini sering dikunjungi ketika paket data internet yang dimiliki oleh orang-orang habis. Pelayanan yang ramah menjadi nilai tambah bagi konter tersebut, akan tetapi disisi penjualnya yang ramah dan banyak digemari oleh pelajar, konter tersebut melakukan sebuah kesalahan yaitu adanya masa aktif paket data internet yang tidak sesuai dengan masa aktif yang tertera 
di bungkus kartu perdana. Masalah ketidaksesuaian ini tidak hanya terjadi sekali, akan tetapi berulang kali. Padahal banyak juga yang masa aktif paket data internetnya sama dengan yang dibungkus kartu perdana.

\section{Akad Jual Beli Masa Aktif Paket Data Internet}

Akad dalam bahasa Indonesia dikenal dengan istilah perjanjian, Perikatan, atau kontrak. Perjanjian berarti suatu peristiwa yang mana seseorang berjanji kepada orang lain atau pihak lain (perorangan atau badan hukum) atau suatu peristiwa yang mana dua orang atau pihak saling berjanji untuk melakukan suatu hal. Akad dalam islam memiliki cerpen yang luas, yaitu pada semua bentuk perjanjian atau kesepakatan yang melibatkan kedua belah pihak atau lebih melaui sebuah ijab dan qobul, baik ijab qobul dalam nikah, akad jual beli, maupun akad transaksi lainya. Akad-akad tersebut baru sah dan efektif apabila telah memenuhi rukun dan syarat yang telah ditetapkan oleh syari'at. Perbedaan dari akad-akad tersebut hanya terletak pada lafaz-lafaz ( penyebutan) menurut apa yang diakadkan.( Rahmawati, 2011: 25).

Dalam praktiknya, akad telah dikenal oleh masyarakat. Menurut penelitian ahli hukum islam, akad muncul sesudah adanya penguasaan atau klaim terhadap benda yang belum pernah dimiliki oleh orang lain, karena akad baru dapat dilakukan apabila ada suatu hal yang dapat diikatkan dengan orang lain. Orang akan membutuhkan suatu akad perjanjian atau perikatan ketika ada suatu hal yang berharga dan setiap orang memilikinya menganalisa hal tersebut akan membawa pada pemahaman bahwa akad telah ada sejak manusia bermasyarakat.

Dalam penelitian ini menggunakan akad jual beli, yang mana antara penjual dan pembeli sudah melakukan kesepakatan, kemudian terjadi ijab dan qobul ditempat tersebut. Pembeli memberikan uang yang seharga dengan barang tersebut dan penjual memberikan barang yang sudah menjadi kesepakatan antara penjual dan pembeli dalam satu waktu ditempat tersebut. Manusia tidak dapat dipisahkan dari pergaulanya dengan sesama manusia dan alam sekitarnya, ia bebas berinteraksi dengan siapa saja yang diinginkanya. Oleh karena itu, Allah 
Swt, mensyariatkan di dalam islam untuk bermuamalah dengan baik, yaitu dengan menggariskan beberapa prinsip yang harus ditaati agar manusia dapat merasakan kemaslahatan didalam bermuamalahnya itu, serta menghindarkan mereka dari hal-hal yang merusaknya.

Sistem Penjualan dalam hal ini, orang yang mebutuhkan paket data internet langsung membeli ke konter komplek Pasar Tamansari. Harga dan produknya berbeda-beda, tergantung pembeli akan membeli paket data yang mana dan jumlah kuotanya berapa serta masa aktif yang lamanya berapa bulan. Produk yang dijual tersebut antara lain simpati, smartfreen, Axis, Xl, indosat dan produk lainya. Jumlah kuotanya juga berbeda-beda ada yang 1 GB, 2GB sampai 10GB. Mengenai masa aktifnya, rata-rata yang diperjual-belikan yaitu antara 1 sampai dengan 3 bulan. Semakin lama masa aktif tersebut, maka harganya juga semakin mahal.

Dalam proses jual-beli harus memenuhi rukun jual-beli yaitu : (1) Orang yang berakad (Penjual dan Pembeli), Penjual yang dimaksud disini adalah penjual paket data internet yang berada di konter komplek Pasar Tamansari dan pembelinya yaitu yang membeli paket data internet tersebut. Untuk mendapatkan paket data internet yang sesuai dengan kebutuhan, pembeli langsung datang ke konter tersebut. Untuk melihat paket data internet yang dicari dan memilihnya. Berbagai macam paket data internet dijual di konter tersebut dengan harga yang berbeda-beda tergntung berapa GB yang akan dibeli.

Dalam prosesi ijab Qobul, Sebelum pendapatkan paket data internet yang akan dibeli, pembeli menanyakan terlebih dahulu berapa GB isi paket tersebut dan berapa lama masa aktif paket tersebut. Dalam hal ini pembeli menanyakan paket data internet telkomsel 30GB. Penjual membertitahukan bahwa masa aktif paket data internet yang akan dibeli pembeli tersebut yaitu 2 bulan, sama seperti yang tertera didalam kemasan (Zebua, 2018). Kemudian penjual memberitahukan kepada pembeli tentang harga paket data tersebut dan selanjutnya terjadi kesepakatan antara pembeli paket telkomsel dan pemilik konter dengan harga yang sudah ditentukan. Dalam hal ini ada pembeli lain yang 
membeli paket data internet di konter tersebut, yaitu membeli paket data indosat 3GB dengan masa aktif 2 bulan penjual memberitahukan hal yang sama. Masa aktif data paket internet tersebut sama dengan yang sudah tertera dalam kemasan.( Zebua, 2018). Setelah selang beberapa hari paket data tersebut tidak bisa digunakan lagi padahal paket data dan masa aktif masih ada dari tanggal berlaku yang pernah dikatakan oleh penjual sewaktu membeli paketan. pembeli penasaran akhirnya mengecek paket data internet telkomsel 30GB dan indosat 3GB dari sini pembeli baru menyadari bahwa adanya ketidaksesuaian dengan apa yang diberitahukan oleh penjual, yaitu masa aktif paket data internet tidak sama dengan yang tertera di dalam kemasan. (2) Barang yang dibeli (Ma'qud 'alaih), Barang yang dibeli dikonter tersebut adalah paket data internet telkomsel 30Gb yang tertera di dalam kemasan bahwa masa aktifnya yaitu 2 bulan dan indosat $3 \mathrm{~Gb}$ yang dalam kemasan tersbut tertera masa aktif 2 bulan. (Ida, 2018). (3) Nilai Tukar pengganti barang, Alat tukar yang digunakan dalam jual beli adalah Uang. Pembeli memberikan sejumlah uang yang sudah disepakati antara penjual dan pembeli mengenai produk yang dibeli.

Smarphone tidak dapat digunakan untuk keperluan diatas tanpa adanya paket kuota data internet. kuota merupkan batasan, kuota yang dimaksud dalam internet ini merupakan batasan satuan paket internet yang diperbolehkan pada pembelian satu paket. Jika kuota terlampaui koneksi internet akan terputus dan harus mengisi lagi dengan kuota tambahan jika ingin dapat digunakan lagi. Kuota dalam paket ini merupakan batasan paket yang diberikan operator yang mana pelanggan dapat menggunakanya untuk akses internet, umumnya sekarang dalam hitungan $\mathrm{Gb}$ atau sama dengan $1000 \mathrm{Mb}$. Kuota pada paket ini dibagi menjadi beberapa jenis, seperti kuota utama, kuota bonus, kuota malam dan lain sebagainya. Makna dan arti mengacu pada batasan penggunanya. Smartphone juga tidak dapat digunakan untuk keperluan-keperluan diatas jika masa paket data internet telah habis, walaupun sisa kuota yang ada di dalamnya masih banyak akan tetapi masa aktifnya sudah habis, maka tidak dapat digunakan untuk mengakses internet. Masa aktif merupakan waktu dimana kartu prabayar dapat digunakan selama 1 bulan jika tidak diisi pulsa. Akan tetapi jika waktu kurang 
dari satu bulan dari masa kartu prabayar diisi pulsa maka masa aktif kartu tersebut akan diperpanjang. Dan sebaliknya jika kartu tidak diisi pulsa maka masa aktifnya tetap seperti yang tertera dalam kemasan.

Dalam pelaksanaan penjualan, orang yang membutuhkan paket data internet langsung membeli ditempat tersebut. Harga dan produknya berbedabeda, tergantung pembeli mau beli paket data yang mana dan jumlah kuotanya berapa serta masa aktif yang lamanya berapa bulan. Produk-produk yang dijual tersebut antara lain indosat, Tri, Telkomsel, Smartfreen dan lain sebagainya. Jumlah kuotanya juga berbeda-beda ada yang $1 \mathrm{~Gb}, 2 \mathrm{~Gb}$ sampai dengan $30 \mathrm{~Gb}$ serta mengenai masa aktifnya, rata-rata yang diperjualbelikan yaitu antara 1 sampai dengan 3 bulan. Semakinn lama masa aktif maka semakin mahal harganya. Jual beli diatas secara umum sudah memenuhi syarat, yaitu: Adanya penjual dan pembeli, Objek jual beli ini adalah masa aktif paket data internet, Terdapat alat tukar yaitu berupa uang dan objeknya masa aktif paket data internet, Jual beli dilakukan secara langsung di tempat, Terjadi kesepakatan antara penjual dan pembeli. Dalam hal ini pembeli langsung ke konter, membeli paket data intenet telkomsel $30 \mathrm{~Gb}$ yang dikatakan penjualnya bahwa masa aktif kartu perdana tersebut yaitu dua bulan. (Anna, 2018). alasan penjual terhadap kasus yang terjadi yaitu karena pada dasarnya masalah masa aktif tersebut sudah dari pusatnya aktif tetapi ada juga yang belum aktif. Kemudian kekurangan dalam masa aktif tersebut dikarenakan penjual tidak menembakkan masa aktif pada kartu paket data internet trsebut.( Agus, 2018). Akan tetapi dalam jual-beli ada kecacatan yang terkait dengan kesepakatan yang dilakukan, adanya ketidaksesuaian terhadap objek yang dibeli,. Hal ini baru dapat diketahui setelah pembeli mengaktifkan kartu paket data internet tersebut dan mengecek masa aktifnya.hal ini tentunya dapat merugikan pembeli. Dalam penjualan ini beresiko terdapata unsur penipuan.

\section{Analisis Hukum Islam terhadap Jual Beli Paket Data Internet}


Jual-beli adalah suatu perjanjian tukar-menukar benda yang mempunyai nilai, atas dasar kerelan atau kesepakatan anyara kedua belah pihak dengan yang sesuai perjanjian atau ketentuan yag telah dibenarkan oleh syara', bahwa dalam jual-beli harus memenuhi rukun dan syarat-syaratnya dan hal-hal lain yang ada kaitanya dengan jual-beli. Maka apabila rukun dan syarat tersebut tidak terpenuhi berarti tidak sesuai dengan kehendak dan ketentuan syara'. Semakin banyaknya masyarakat yang memiliki smarphone, menjadikan kebutuhan paket kuota internet semakin meningkat. Hal ini menjadikan banyak orang yang melakukan jual beli paket kuota data internet sebagai bisnis dan mendirikan counter, seperti halnya counter di komplek pasar tamansari. Pemilik menjadikanya bisnis untuk memperjualbelikan paket kuota data internet dan keperluan-keperluan smartphone lainnya. Jumhur ulama' menyatakan bahwa rukun jual-beli itu ada 4, yaitu: Orang yang berakad ( penjual dan pembeli), ijab dan qobul, barang yang dibeli, nilai tukar pengganti barang.

Adapun syarat benda yang dapat diperjualbelikan yaitu: (1) Benda tersebut harus suci, Adanya manfaat,(2) Barang tersebut dapat diserahkan, artinya barang tersebut harus ada ketika ditransmisikan, tidak boleh menjual barang yang masih belum pasti,(3) Barang tersebut milik sendiri, kalaupun barangnya milik orang lain, harus ada perizinan dengan orang yang bersangkutan. (4) Barang tersebut diketahui oleh penjual dan pembeli, baik bentuk, maupun sifat yang jelas sehingga tidak ada yang dirugikan dikemudian hari.( Sulaiman Nasjid, 2010: 279).

Dalam Al-Qur'an surat An-Nisa ayat 29 dijelaskan,

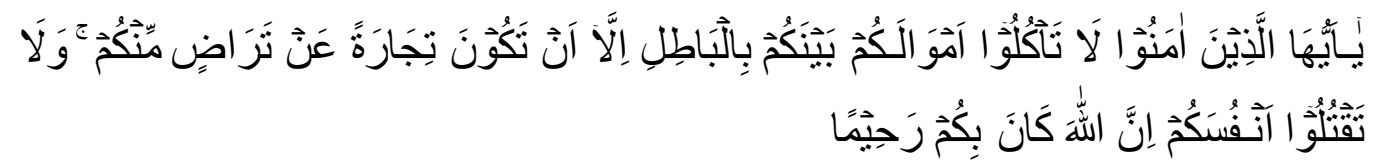

Artinya:"Hai orang-orang yang beriman, janganlah kamu saling memakan harta sesamamu dengan jalan yang batil, kecuali dengan jalan perniagaan yang berlaku dengan suka sama suka diantara kamu. dan janganlah kamu membunuh 
dirimu. Sesungguhnya Allah adalah Maha Penyayang kepadamu.'(Al-Qur'an dan Terjemahnya: 107)

Dari penjelasan ayat di atas menekankan bahwa dalam kegiatan jual beli apa saja dalam bentuk jual beli diperbolehkan selama didasarkan pada sikap sama- sama ridha dari kedua belah pihak dan selama tidak dilarang oleh Allah swt.1 Dalam hal ini objek jual beli sangat berpengaruh terhadap kaidah diatas. Khususnya Jual beli masa aktif paket data internet dengan objek transaksi yang tidak sesuai dengan kesepakatan awal dan menimbulkan kerugian salah satu pihak.

Dari pemaparan di atas dari sudut pandang obyek transaksi yang diperjualbelikan terdapat ketidakjelasan mengenai kadar, kualitas dari obyek tersebut karena ada percampuran dalam obyeknya. Walaupun dalam praktiknya sudah ada kesepakatan di awal namun pada kenyataannya salah satu pihak ada yang dirugikan dan dari pihak penjual terkesan memanipulasi dari adanya spesifikasi barang yang dijualnya.( Nasroen Harun, 2000: 237) Dalam hadith dijelaskan, yang artinya.

"Telah menceritakan kepada kami [Abu Bakr] dan [Utsman] dua anak Abu Syaibah?, mereka berkata; telah menceritakan kepada kami [Ibnu Idris] dari ['Ubaidullah] dari [Abu Az Zinad] dari [Al A'raj] dari [Abu Hurairah] bahwa Nabi shallallahu 'alaihi wasallam melarang menjual secara ghaghar (transaksi jual beli yang mengandung unsur ketidakjelasan, penipuan, pertaruhan, dan hal-hal yang merugikan), sedang Utsman menambahkan dan hashah (transaksi jual beli yang dilakukan oleh dua orang tetapi barangnya belum jelas, kemudian untuk menentukannya salah satu dari mereka melempar hashat (kerikil), maka barang yang terkena kerikil itulah yang dijual)."( Abu Dawud, Sunan Abu Dawud, 1997: 4441.)

Dalam hadits diatas dijelaskan bahwa barang yang telah tercampur dan tidak diketahui oleh pembeli maka erat dengan penipuan, karena ada pengurangan dari kualitas obyek trasaksi tersebut dan tidak ada dalil yang membolehkannya.Jual beli yang keluar dari ketentuan syara ${ }^{\text {ee }}$ harus ditolak atau tidak dianggap, baik dalam muamalat maupun ibadah. 
Dari analisa diatas ada ketidaksesuaian terhadap syarat akad yaitu ma'qud 'alaih Penjual tidak mengatakan yang sebenarnya kepada pembeli terkait dengan masa aktif pada paket data internet, padahal dalam syarat akad tersebut dijelaskan bahawa barang yang diperjual belikan harus jelas dan sesuai. Jual beli masa aktif paket data internet di Konter Komplek Pasar Tamansari tidak memenuhi Ma'qud'alaih karena ada ketidakjelasan terhadap kadar maupun kualitas dari barang tersebut, maka jual beli tersebut menjadi rusak (fasid) atau batal.

\section{KESIMPULAN}

Konter Komplek Pasar Tamansari merupakan konter yang digemari oleh masyarakat, khususnya oleh pelajar, karena mempunyai harga yang cukup terjangkau, bisa dikatakan lebih murah daripada tempat yang lainya, tempatnya yang sangat strategis dan tidak terlalu jauh dari sekolahan membuat tempat ini sering dikunjungi ketika paket data internet yang dimiliki oleh orang-orang habis. Pelayanan yang ramah menjadi nilai tambah bagi konter tersebut, akan tetapi disisi penjualnya yang ramah dan banyak digemari oleh pelajar, konter tersebut melakukan sebuah kesalahan yaitu adanya masa aktif paket data internet yang tidak sesuai dengan masa aktif yang tertera di bungkus kartu perdana. Masalah ketidaksesuaian ini tidak hanya terjadi sekali, akan tetapi berulang kali. Padahal banyak juga yang masa aktif paket data internetnya sama dengan yang dibungkus kartu perdana.

Pada dasarnya hukum jual-beli tersebut adalah sah, karena Sesuai dengan rukun dan syarat jual beli. Akan tetapi pada obyek transaksi tersebut terdapat ketidaksesuaian dengan kesepakatan awal yang telah dipaparkan oleh penjual, dalam hal ini terdapat unsur penipuan karena Penjual memberitahukan kepada pembeli bahwa objek tersebut sama seperti pada apa yang tertera dalam kemasan produk. Akan tetapi saat pembeli mengaktifkan dan mengecek kartu perdana trsebut tidak sama dengan apa yang telah diberitahukan oleh penjual. Dalam hal ini maka secara manfaat tidak terpenuhi sepenuhnya karena adanya kecacatan terhadap objek yang diperjualbelikan maka jual-beli tersebut rusak atau batal. 
Dan juga terdapat kerugia dari pihak pembeli mengenai kekurangan masa aktif paket data internet yang diperjualbelikan.

Seharusnya sebagai penjual yang baik kita harus menerapkan ajaran perdagangan sesuai syariat agama islam dengan meneladani sifat Rasulullah dahulu yaitu berdagang dengan menerapkan sifat jujur. misalnya dalam hal jual pakat data ini sebagai penjual harus jujur jikalau memang pakat data yang akan dijual masa aktifnya habis maka itu tidak layak dijual lagi atau bisa jadi memberitahu kepada pembili jika ada kekeliruan dalam masa aktif paket data boleh menukarkan kartu paket data tersebut agar pembeli nyaman dengan pelayanan di counter yang sedang kita rintis ini dan itu juga akan menguntungkan bagi pemilik conter karena itu akan menjaga nama baik usaha yang dirintis tersebut dan menjadikan pembeli percaya akan fasilitas yang diberikan oleh conter tersebut.

\section{DAFTAR PUSTAKA}

Abu Dawud, Sunan Abu Dawud', 1997, Hadith no.2932. Kitab: al-Buyu', Bab: Fi Ba'i alGharar dalam Mausu'ah al-Hadis al-Syarif..Ahmad, Musnad Ahmad'.Hadith no.893 edisi ke-2, t.tp: Global Islamic Software Company

Al-Qur'an Tarjamah, 2005, Al-Jumanatul Ali, Penerbit : J-ART Anggota IKAPAI

Cholid Narbuko dan Abu Ahmadi, 1997, Metodologi penelitian, Jakarta: Bumi Aksara

Departemen Agama Republik Indonesia, Al-Qur'an dan Terjemahanya Ghazaly, Abdur-Rahman, dkk, 2012, Fiqh Muamalat cet 2, Jakarta: Kencana Huda,Qomarul, 2011, Fiqh Mu'amalat,Yogyakarta: Teras

Imam Ahmad Bin Husain, Fathul-Qarib Al-Mujib, Surabaya:Al-Hidayah Nasroen Harun, 2000, Fiqh Muamalah, Jakarta:Media Pratama

Rahmawati, 2011, Dinamika Akada dalam Transaksi Ekonomi Syariah", Jurnal Al-Iqtishad (Jakarta), vol.3 nomor 1

Sulaiman Nasjid, 2010, Fiqih Islam, cet ke-46, Bandung: Sinar Baru Algesindo Sukudir dan Mundir, 2015, Metode Penelitian: Menimbang dan Mengantar Kesuksesan Anda dalam Dunia Penelitian, Surabaya: Insan Cendekia Wahbah Az-Zuhaily, 2005, Al-Fiqh al-Islami Wa Adillatuh, Damaskus 